\title{
Assessment of private Sector Employees in Terms of Education in Northern Cyprus
}

\section{Evaluación de los empleados del sector privado en términos de educación en el norte de Chipre}

\author{
Ziya ÖZTÜRKLER \\ Cyprus Health and Social Sciences University, Mersin 10 Turkey.
}

*Correspondence

Email: ziyaozturkler@gmail.com

\section{Cite as:}

ÖZTÜRKLER, Z. (2020). Assessment of private Sector Employees in Terms of Education in Northern Cyprus. Propósitos y Representaciones, 9 (SPE1), e854. Doi: http://dx.doi.org/10.20511/pyr2021.v9nSPE1.e854 


\section{Summary}

Nowadays, we must follow the rapid advances in technology and the implementation of competitive activities that the most important of them are educational activities. It is found that professions that do educational activities exhibit better financial performance than jobs that do not this. In this research, it is tried to specify the perceptions and views of employees of private sector companies in Northern Cyprus concerning the purpose of education, determination of training needs, implementation of education, and assessment of the education program. The objective of this study was to determine whether there is a difference in the perceptions and views of employees working in the private sector, especially in Northern Cyprus, regarding their performance and evaluation in academic fields. As a result, according to the results of the survey applied, there is a significant relationship between the importance given to education and the evaluation of the amount of education in private sector companies in northern Cyprus, for educational activities and development are essential and mandatory for employees working in companies. If the results of the training assessment used after education are reliable in the companies, the results will be also employed in the next education.

Keywords: Education, Management, Knowledge, Private Sector, Quality.

\section{Resumen}

Hoy en día, debemos seguir los rápidos avances de la tecnología y la implementación de actividades competitivas que la más importante de ellas son las actividades educativas. Se encuentra que las profesiones que realizan actividades educativas presentan un mejor desempeño financiero que los trabajos que no lo hacen. En esta investigación, se intenta especificar las percepciones y puntos de vista de los empleados de las empresas del sector privado en el norte de Chipre con respecto al propósito de la educación, la determinación de las necesidades de capacitación, la implementación de la educación y la evaluación del programa educativo. El objetivo de este estudio fue determinar si existe una diferencia en las percepciones y puntos de vista de los empleados que trabajan en el sector privado, especialmente en el norte de Chipre, con respecto a su desempeño y evaluación en los campos académicos. Como resultado, de acuerdo con los resultados de la encuesta aplicada, existe una relación significativa entre la importancia que se le da a la educación y la evaluación de la cantidad de educación en las empresas del sector privado en el norte de Chipre, ya que las actividades educativas y el desarrollo son esenciales y obligatorios para empleados que trabajan en empresas. Si los resultados de la evaluación de la formación utilizada después de la formación son fiables en las empresas, los resultados también se utilizarán en la próxima formación.

Palabras clave: Educación, Gestión, Conocimiento, Sector Privado, Calidad.

\section{Introduction}

today, human force is among the factors that provide all the success. the human factor is an accepted idea that they will have a relative superiority over their competitors as a competitive advantage. in the current conditions of global competition, adapting to new competitive conditions for countries, and even individuals have become a strategic priority. twenty-first-century societies will consist of informed and knowledgeable workers, and they will have to constantly renew and update themselves. in this era, production, dissemination, and use of science in the right place are more and more important than knowing science. one of the essential human resource management activities is education and the process of creating favorable changes in the behavior of private- 
sector employees in a planned manner. education refers to the efforts planned by the company to facilitate the prediction of work-related competencies (eren, 2003; dursun, 2003; gençer, 2006).

in this study, it is noteworthy that studies associated with the education of private sector companies in northern cyprus are generally aimed at determining the training methods in these companies. as disclosing the current state of education in private sector companies is of great importance in making improvements related to education in occupations, determining perceived forms of training practices by employees can also be an important source of information to meet their academic expectations (clear \& seager, r., 1971).

in this study, it is attempted to specify the perceptions of employees working in private sector companies in northern cyprus concerning the purpose of education, determination of training needs, implementation of education, and assessment of the education program. the objective of this study was to determine whether there is a difference in the perceptions and views of employees working in the private sector, especially in northern cyprus, regarding their performance and evaluation in academic fields. on the basis of this assumption, it is conceived that this may contribute to the subject in literature/content.

\section{the research model}

in this study, the education management of private-sector employees in northern cyprus and employees' views on the evaluation of education are examined and defined.

\section{data collection tools}

in the present study, a questionnaire was used as a tool for data collection. the face-to-face surveys and emails were used for the distribution and collection of surveys.

the questionnaire, which is applied to specify the education management of private-sector employees in northern cyprus and determine their views on the evaluation of employees' education, includes two main sections consisting of information on demographic profiles of employees and questions for evaluation. to evaluate the data collection tool, a 5-point likert scale 
was employed. scale evaluation was as follows: 1) strongly disagree 2) disagree 3) neither agree nor disagree (unsure) 4) agree 5) strongly agree

the reliability and validity of the scale applied to employees in various private sector companies were tested, and the cronbach's alpha value was obtained to be 0.64 (gençer, 2006).

data analysis

the data achieved in the study were evaluated using spss20 software. the statistical t-test and frequency were used in analyzing the survey data.

\section{Results and Comments}

the findings related to demographic variables:

table 1: distribution of participants based on gender

\begin{tabular}{lll}
\hline gender & distribution & percentage \\
\hline female & 185 & $62 \%$ \\
male & 115 & $38 \%$ \\
\hline total & 300 & $100 \%$ \\
\hline
\end{tabular}

at the time of observing the gender of participants in table 1, of 300 people, $185(62 \%)$ are female, and $115(38 \%)$ are male. we can see from the table above that most of the participants in this study are women.

table 2: distribution of participants based on age

\begin{tabular}{l|l|l}
\hline age & distribution & percentage \\
\hline $25-35$ & 77 & $26 \%$ \\
$35-40$ & 93 & $31 \%$ \\
$40-45$ & 85 & $28 \%$ \\
$45-50$ & 45 & $15 \%$ \\
\hline total & 300 & $100 \%$ \\
\hline
\end{tabular}

according to the distribution of participants by age in table 2, among the 300 participants, 77 people aged 25 to 35 years (26\%), 93 people aged 35-40 years (31\%), 85 people aged $40-45$ years (28\%), and 45 people aged $45-50(15 \%)$. moreover, it can be seen from the table that participants in this study mainly aged 35 to 40 years $(31 \%)$

table 3: distribution of participants based on their educational level

\begin{tabular}{lll}
\hline educational level & distribution & percentage \\
\hline bachelor's degree & 111 & $37 \%$ \\
master's degree & 153 & $51 \%$ \\
ph.d. degree & 36 & $12 \%$ \\
\hline total & 300 & $100 \%$ \\
\hline
\end{tabular}

according to the distribution of participants based on their educational levels in table 3, out of 300 participants, 111 people have bachelor's degrees (37\%), 153 people have master's degrees $(51 \%)$, 
and 36 people have ph.d. degrees (12\%). we can see from the table above that the participants in this study are mostly master's degrees (professors).

table 4: distribution of participants based on their distribution of duties

\begin{tabular}{lll}
\hline position/duty & distribution & percentage \\
\hline lower-level manager & 99 & $33 \%$ \\
middle-level manager & 114 & $38 \%$ \\
senior manager & 87 & $29 \%$ \\
\hline total & 300 & $100 \%$ \\
\hline
\end{tabular}

according to the distribution of participants based on their job status in table 4, among the 300 participants, 99 people are lower-level managers (33\%), 114 people are middle-level managers (38\%), and 87 people are senior managers (29\%). we can observe from the above table that the participants in this study are mostly middle-level managers.

table 5: distribution of participants by the private sector in which they work

\begin{tabular}{|l|l|l|}
\hline business & distribution & percentage \\
\hline bank employees & 160 & $53 \%$ \\
\hline private school employees & 104 & $35 \%$ \\
\hline tourism agency employees & 36 & $12 \%$ \\
\hline total & 300 & $100 \%$ \\
\hline
\end{tabular}

when we examine the distribution of participants in table 5 based on their job status, out of 300 participants, $164(53 \%)$ people are bank employees, $104(35 \%)$ people are private school employees, and 36 people are (12\%) tourism agency employees. we can see from the table above that the participants in this study are mostly bank employees.

the findings and opinions about research questions:

table 6: the destination in which employees want to achieve education is the improvement of themselves.

\begin{tabular}{|l|l|l|}
\hline questions & distribution & percentage \\
\hline strongly disagree & 7 & $2 \%$ \\
\hline disagree & 15 & $5 \%$ \\
\hline neither agree nor disagree (unsure) & 20 & $7 \%$ \\
\hline agree & 87 & $29 \%$ \\
\hline strongly agree & 171 & $57 \%$ \\
\hline total & 300 & $100 \%$ \\
\hline
\end{tabular}

when we examine table 6 , i.e., the responses of private-sector employees in northern cyprus to the question "the purpose of access to education is the growth and promotion of themselves", it is found that 7 (2\%) of the participants strongly disagree, $15(5 \%)$ disagree, $20(7 \%)$ neither agree 
nor disagree (unsure), 87 (29\%) agree, and 171 (57\%) strongly agree, respectively. this is because one of the social goals is that employees want to improve themselves.

table 7: the difference in sector affects the performance of education

\begin{tabular}{lll}
\hline questions & distribution & percentage \\
\hline strongly disagree & 10 & $3 \%$ \\
disagree & 19 & $6 \%$ \\
neither agree nor disagree (unsure) & 50 & $17 \%$ \\
agree & 109 & $36 \%$ \\
strongly agree & 112 & $37 \%$ \\
\hline total & 300 & $100 \%$ \\
\hline
\end{tabular}

in table 7, when we look at the questions asked by private-sector employees in northern cyprus about the question "the difference in sector affects the performance of education," 10 (3\%) of the participants strongly disagree, $19(6 \%)$ disagree, 50 of them neither agree nor disagree (unsure) (17\%), $109(36 \%)$ agree, $112(37 \%)$ strongly agree, respectively. this is because employees upgrade their performance by learning new information and improving themselves.

table 8: improving the quality of work is one of the objectives of employees

\begin{tabular}{lll}
\hline questions & distribution & percentage \\
\hline strongly disagree & 3 & $1 \%$ \\
disagree & 9 & $3 \%$ \\
neither agree nor disagree (unsure) & 91 & $30 \%$ \\
agree & 96 & $32 \%$ \\
strongly agree & 101 & $34 \%$ \\
\hline total & 300 & $100 \%$ \\
\hline
\end{tabular}

in table 8 , when we examine the responses of private-sector employees in northern cyprus to the question "improving the quality of work is one of the objectives of employees," $3(1 \%)$ of the participants strongly disagree, 9 (3\%) disagree, 91 neither agree nor disagree (unsure) (30\%), 96 (32\%) agree, 101 (34\%) strongly agree, respectively. when we observe the responses given, we find that the goal of the participants for education is to enhance the quality of work.

table 9: education is not considered important in private-sector companies

\begin{tabular}{lll}
\hline questions & distribution & percentage \\
\hline strongly disagree & 3 & $1 \%$ \\
disagree & 101 & $34 \%$ \\
neither agree nor disagree (unsure) & 9 & $3 \%$ \\
agree & 90 & $30 \%$ \\
strongly agree & 97 & $32 \%$ \\
\hline total & 300 & $100 \%$ \\
\hline
\end{tabular}

by looking at the responses of private-sector employees in northern cyprus to the question "education is not considered important in private-sector companies," in table 9, $3(1 \%)$ of the participants strongly disagree, 101 (34\%) disagree, 9 (3\%) neither agree nor disagree (unsure), 90 (30\%) agree, while $97(32 \%)$ strongly agree, respectively. 9 (3\%) of the participants announced that they care education in their jobs and 97 (32\%) stated that they did not care about education 
in their jobs. as a result, $30 \%$ of respondents stated that education in jobs is of importance, and $3 \%$ stated that they are not neutral (neither agree nor disagree).

table 10: tools such as survey management, training needs assessment form, and interview method should be applied in the analysis of training needs

\begin{tabular}{lll}
\hline questions & distribution & percentage \\
\hline strongly disagree & 5 & $2 \%$ \\
disagree & 7 & $3 \%$ \\
neither agree nor disagree (unsure) & 156 & $52 \%$ \\
agree & 47 & $16 \%$ \\
strongly agree & 85 & $28 \%$ \\
\hline total & 300 & $100 \%$ \\
\hline
\end{tabular}

when we examine the responses to the question of employees working in the private sector in northern cyprus to the question "tools such as survey management, training needs assessment form, and interview method should be applied in the analysis of training needs", $5(2 \%)$ of the participants strongly disagree, 7 (3\%) disagree, 156 (52\%) neither agree nor disagree (unsure), 47 $(16 \%)$ agree, and $85(28 \%)$ strongly agree, respectively.

as a result, $16 \%$ of the participants announced that the use of tools such as questionnaire management, training needs assessment form, and interview method is very important in the analysis of training needs, and $85 \%$ of them strongly agree.

\section{Conclusion}

the purpose of education is that it puts the knowledge, skills, and behaviors based on training programs and employs them in daily work of social life. in this context, the educational activities conducted by private-sector companies have economic and social goals. the goals that jobs want to reach them by education are to increase production and improve quality. overall, the bank believes that the purpose of the jobs is to increase production and improve the quality of employees working in private sectors and tourism agencies (balci, 1993; adorno \& horkheimer, 2010; bursalioğlu, 2002).

educational activities have an essential place in private-sector companies. the survey exhibited that disagree with private-sector employees on their importance to education. however, businesses should pay attention to educational activities and development of employees in terms of operational quality that have both service activities and manufacturing axes since employees' knowledge increases with education and skills. as a result, they deliver high-quality services. the application of the concept of social capital-based management is quite important as well (erlangga et.al, 2019). the main objective of the process of determining training needs is to ensure the realization of the need for education and the definition of the content of the training program (adorno \& horkheimer, 2010).

they think differently about using tools such as the training needs assessment form and interview method to analyze the needs of employees working in the private-sector companies in northern cyprus. while assessing learning after education and evaluating changes in employee behavior, measuring the effectiveness of education and determining the progression of employees with education is important. according to miner (2006) successful managers are defined as those who accurately and flexibly adjust their behavior to various situational constraints on the choice of a leadership pattern. leadership is important requirement whenever people gather as teams to accomplish certain tasks (bodla \& nawaz, 2010)

taking into account the results of this survey used, there is a significant relationship between the importance given to education and the evaluation of education in private-sector companies in 
northern cyprus, for educational activities and development are essential and mandatory for employees working in companies. if the results of the education evaluation applied after the education is reliable in the companies, the results will be used in the next education. the goals of companies are learning, development of their knowledge, skills, attitudes, and behaviors and adaptation of the acquired behaviors in line with what has been learned. important jobs that care about education support their participation in educational activities so that their employees can improve themselves. tutors have to develop and practice a multitude of skills and strategies. (kao \& chou, 2018)

due to the existence of increasing the knowledge and skills of employees participating in this education, they can provide more added value and increase their motivation (neiman, 1986; flamer, 2004).

\section{References}

Adorno, T. W. \& Horkheimer, M. (2010). Aydınlanmanın diyalektiği (Çev. N. Ünler ve E. Ö. Karadoğan). İstanbul: Kabalcı Yayınevi.

Balcı, A. (1993). Eğitim Örgütlerine Yeni Bakış Açıları: Kuram - Araştırma İlişkisi. Ankara Üniversitesi Ë̆itim Bilimleri Fakültesi Dergisi, 25 (1), 27-45.

Bodla, M. A., \& Nawaz, M. M. (2010). Comparative study of full range leadership model among faculty members in public and private sector higher education institutes and universities. International Journal of Business and Management, 5(4), 208.

Bursalığlu, Z. (2002). Okul yönetiminde yeni yapı ve davranış. Ankara: Pegem Yayıncılık.

Clear, P. K.\&Seager, R. C. (1971). The legitimacy of administrative influence as perceived by selected groups. Educational Administrative Quarterly, 7, 46-63.

Dursun, B (2003). İnsan kaynakları yönetimi.5. Bask1, İstanbul: Beta Basım Yayını.

Eren, E. (2003). Yönetim ve organizasyon. İstanbul: Beta Basım Yayın Dağıtım.

Erlangga, E., Sugiyo, H., \& Prihatin, T. 2019, School Management of Social Capital Based To Improve Teacher's Performance, ISET 201929 June Semarang Indonesia. DOI 10.4108/eai.29-6-2019.2290281

Flamer, A. S. D. (2004). The relationship between personal characteristics of principals and their perception of school leadership authority. Unpablished doctoral dissertation, Morgan State University.

Gençer, B. B. (2006). Eğitim Yönetimi ve Çalışanların Eğitim Değerlendirmesine Bakışı. Yüksek Lisans Tezi, Yıldız Teknik Üniversitesi, İstanbul.

Kao, H.-H., \& Chou, C.-H. (2018). English Online Tutoring: A Study of University Students Learning to Teach Junior High Students. Mediterranean Journal of Social \& Behavioral Research, 2(1), 3-7. doi.org/10.30935/mjosbr/8381

Miner, J. B. (2006). Organizational Behavior 1: Essential Theories of Motivation and Leadership, M.E. Sharpe, Inc. New York.

Neiman, A. M. (1986). Education, power and the authority of knowledge. USA: Teachers College Record, 88. 